\title{
STUDY OF THE INFLUENCE OF BUCKWHEAT FLOUR AND FLAX SEEDS ON CONSUMPTION PROPERTIES OF LONG-STORED BAKERY PRODUCTS
}

\author{
Yulia Bondarenko \\ Department of Technology of bakery and confectionery products \\ National University of food technologies \\ 68 Volodymyrska str., Kyiv, Ukraine, 01601 \\ bjuly@ukr.net \\ Larysa Mykhonik \\ Department of Technology of bakery and confectionery products \\ National University of food technologies \\ 68 Volodymyrska str., Kyiv, Ukraine, 01601 \\ GMLLora@i.ua \\ Olena Bilyk \\ Department of Technology of bakery and confectionery products \\ National University of food technologies \\ 68 Volodymyrska str., Kyiv, Ukraine, 01601 \\ bilyklena@gmail.com \\ Oksana Kochubei-Lytvynenko \\ Department of Milk and Dairy Technology \\ National University of Food Technologies \\ 68 Volodymyrska str., Kyiv, Ukraine, 01601 \\ okolit@email.ua \\ Galina Andronovich \\ Department of food technologies \\ Cherkasy State Technological University \\ 460 Shevchenko blvd., Cherkasy, Ukraine, 18000 \\ 1gryb1@ukr.net

\section{Inna Hetman} \\ Department of the Technology of Meat Products \\ Institute of Food Resources of NAAS Ukraine \\ 4-A Evgenia Sverstiuk str., Kyiv, Ukraine, 2002
}

\section{Abstract}

Rusk and ring-shaped bakery products relate to the group of long-stored ones. For today it is urgent to use ingredients that give products functional properties in food technologies. The important source of food fibers, full-value protein, unsaturated fatty acids, mineral substances and vitamins are grain and oil-bearing crops. Buckwheat and flax seeds are separated among them due to the valuable chemical composition and positive effect on the human organism.

The aim of the work was to establish the influence of buckwheat flour and flax seeds on the technological process course and quality of long-stored bakery products.

Buckwheat flour of green and dark buckwheat of TM "Organic-Eco-Product" (Ukraine) is used in the rusk technology. For producing ring-shaped products (ring-shaped crackers), gold flax seeds were used.

Research results testify that good quality parameters of bread for producing rusks from it, were achieved at dosing green buckwheat seeds as $20 \%$ and dark ones as $15 \%$ instead of the flour mass.

It has been established, that rusks with adding green buckwheat flour have quality parameters, corresponding to requirements of normative documents. 
It has been proven, that it is not expedient to use dark buckwheat flour in the rusk technology, because ready products have the increased water share and soaking index. It is connected with the influence of the operation of hydrothermal processing of grains that dark buckwheat flour is produced of, its high water-absorbing and water-retaining capacities.

For the technology of ring-shaped crackers, enriched with flax seeds, it is recommended to dose flax seeds as $15 \%$ of the flour mass. At such dosage bakery products got the highest number of points by the complex quality parameter and corresponded to requirements of normative documents.

Keywords: rusks, ring-shaped products, green buckwheat flour, dark buckwheat flour, gold flax seeds.

\section{Introduction}

With the development of nutrition culture, the population demand for products, balanced by the content of main nutritive substances, with the increased food value, increases. Rusk and ringshaped products occupy an important place among bakery products due to their taste and nutritive properties. These products have a low mass share of moisture, so they are bakery "tinned food" that can be stored for a long time and transported at long distances. It conditions the continuous demand of the population for this kind of products.

Today it is urgent to use ingredients that give products functional properties in food technologies. Scientists are interested in substances that come in the gastrointestinal tract with food products and interact with mutagens, decreasing their negative effect. They include food fibers that regulate processes in digestive organs, provides prophylaxis of many human decreases, first of all, so-called "civilization" ones (diabetes mellitus, atherosclerosis, ischemic heart disease, cancer diseases) [1-3].

The important source of food fibers, full-value protein, unsaturated fatty acids, mineral substances and vitamins are grain and oil-bearing crops [4-7].

One of most valuable products of grain crops processing by food and biological value is buckwheat flour. The protein content in buckwheat is within 13.0-15.0\%, that is essentially lower than in other crops (rice $-7.0 \%$, millet $-12.0 \%$, oats $-11.3 \%$ ). Its protein is of the high value, is characterized by the balanced amino acid composition and high content of soluble fractions, well-assimilated by the organism $[8,9]$.

Buckwheat flour is produced of buckwheat peeled grains. Due to the fact that at peeled grains production a part of a buckwheat bud is in the endosperm and is not separated at peeling, the essential amount of vitamins and mineral substances remain in peeled grains. Buckwheat flour is a source of vitamins of E, B, P and PP. It contains in 5-7 times more vitamins of B group, than other peeled grains. Buckwheat contains potassium, phosphorus, magnesium, sodium, copper, iodine, zinc, and it prevails over other peeled grains by the content of calcium and iron. At that, buckwheat flour is rich in food fibers (near $6 \%$ ), organic acids - lemon and apple. Buckwheat is a single grain crop that contains rutin that increases the strength of blood vessels and prevents cardiovascular diseases [10-14].

Among oil-bearing crops, scientists' attention is paid to flax seeds because of their composition of nutritive food substances, able to improve the human health status. The value of flax seeds is in fact that they are a source of such physiological-functional ingredients as unsaturated fatty acids, especially, food fibers and lignins [15].

Flax seeds are a vegetable source of vitally important fatty acids - linoleic (omega-6) and $\alpha$-lenolenic (omega-3). In certain flax sorts the content of $\alpha$-linolenic acid may reach $70 \%$. These essential acids raise the immunity, strengthen walls of blood vessels, increasing their elasticity, so they are used for treating and preventing atherosclerosis and intestinal diseases. Experimental studies on rats proved that $\alpha$-linolenic acid of flax seeds has the important influence in treating and preventing hearth arrhythmias [16].

Researchers of work [17] established that the arterial pressure decrease was favored by the daily consumption of $30 \mathrm{~g}$ of whole flax seeds in the composition of a bakery product by patients with the pulmonary arterial disease and increased arterial pressure. 
Food fibers of flax seeds are characterized with prevailing water-soluble fractions. Water-soluble food fibers of flax form slimes with a high water-retaining capacity that gives them properties of a structure-creator and thickener of food systems [18].

Medical studies proved that slimes of flax seeds favor the improvement of the intestinal microbiota [19].

Flax seeds are a source of vegetable phytoestrogens, phenol compounds, especially lignans (pinoresinol and larisiresinol) with high antioxidant properties. Scientific data prove that lignans of flax seeds have the anti-allergic activity and strong antioxidant effect. Just these their properties are a background of using flax seeds at correcting atherosclerosis and coronary failure [20].

Taking into account such strong physiological properties of flax seeds components, their use in bakery products recipes will favor the improvement of their functional properties.

Among the assortment of bakery products, flax seeds are mainly used in the bread technology [21-23]. There are not enough data about using flax seeds and their processing products in the ring-shaped products technology.

The aim of the work was to establish the influence of buckwheat flour and flax seeds on the technological process course and quality of long-stored bakery products. It allows to produce longstored bakery products, corresponding to requirements of normative documents and having the increased food value, healthy properties as a result of enrichment with components of buckwheat flour and flax seeds.

For attaining the set aim, the following tasks were formulated:

- to establish the optimal dosage of buckwheat flour in simple rusks production for getting products with good consumption properties;

- to establish the optimal dosage of gold flax seeds in ring-shaped crackers production for getting products with good consumption properties.

\section{Materials and Methods}

Buckwheat flour of green and dark buckwheat of TM "Organic-Eco-Product" (Ukraine), according to TC U 15.6-2110615276-002:2010 is used for producing rusks. The quality parameters of buckwheat flour are presented in Table 1.

Table 1

Quality parameters of buckwheat flour

\begin{tabular}{cc}
\hline Name of parameter & Characteristic \\
\hline Color & $\begin{array}{c}\text { Green buckwheat - creamy with a light grey tint; } \\
\text { Dark buckwheat }- \text { light brown }\end{array}$ \\
Taste & $\begin{array}{c}\text { Inherent to buckwheat four, without side smells, not musty, not mouldy } \\
\text { Inherent to buckwheat four, without side smacks, not sour, not bitter }\end{array}$ \\
Consistence & Crackle is nor felt at chewing \\
Mass share of moisture, $\%$ & Green buckwheat -11.6 \\
& Dark buckwheat -8.9 \\
Acidity, degrees & Green buckwheat $-5.4 ;$ \\
\end{tabular}

At preparing ring-shaped products, gold flax seeds of "Biorostoropsha" LTD (Ukraine), according to SSU 4967:2008 were used. The quality parameters of gold flax seeds are presented in Table 2.

For producing rusks and ring-shaped products, where was used wheat flour of the first sort, made by "Kyivmlyn" OSC (according to SSU 46.004-99), kitchen salt of the first sort TM "Artemsil" (according to SSU 3583-2015), pressed yeast of TM "Lviv yeast” (according to SSU 4812:2007), white sugar by TM «Aro» (SSU 4623-2006). 
Table 2

Quality parameters of gold flax seeds

\begin{tabular}{cc}
\hline Name of parameter & Characteristic \\
\hline Outlook & Powdery product, consisted of a mixture of whole kernels \\
Color & Bright, light-yellow \\
Smell and taste & Inherent to flax seeds, without side smacks and smells, signs of must or mould \\
Mass share of moisture, $\%$ & 7.0 \\
Titrated acidity, degrees & 3.0
\end{tabular}

Dark buckwheat flour is obtained by comminuting peeled grains after hydrothermal processing using steam at pressure $0,25 \ldots 0,30 \mathrm{~Pa}$. This flour belongs to ones of special destination, used in child and dietary nutrition.

Green buckwheat flour is obtained of buckwheat peeled grain without thermal processing. This flour has a lighter color, comparing with dark buckwheat one. Its technological properties are little studied, but there is information that its food and biological value exceeds one of dark buckwheat flour due to the absence of hydrothermal processing.

For getting simple rusks and determining their quality parameters, laboratory baking of formed bread of flour mixtures of wheat and buckwheat flour were realized. Experimental samples were added with green and dark buckwheat flour in 15, 20, $25 \%$ instead of the wheat flour mass. The control was a sample of wheat flour without adding buckwheat one. Thus, there were obtained 6 experimental samples (No. 2, 3, 4 with adding green buckwheat flour and No. 5, 6, 7 dark buckwheat flour). The control (sample № 1) for these experimental samples was a sample of wheat flour without adding buckwheat one. The recipe of the control sample: wheat flour of the first sort $-100 \mathrm{~g}$, yeast $-3 \%$, salt $-1.0 \%$.

Bread was cooled during 8 hours, cut in pieces with thickness $15 \mathrm{~mm}$. The obtained pieces were dried at temperature $180^{\circ} \mathrm{C}$ during $30-45 \mathrm{~min}$.

Dough was prepared without preliminary with mass share of dough $42 \ldots 43.6 \%$ depending on the amount of replacement of wheat flour by buckwheat one and, correspondingly, water-absorbing capacity of wheat mixtures. Dough was mixed in two-speed dough-mixing machine Escher (Italy). Dough was processed by hands, dough semi-products were kept in the thermostat at temperature $(38 \pm 2){ }^{\circ} \mathrm{C}$ and relative humidity $(78 \pm 2) \%$ up to readiness. The products were baked in the chamber stove Sveba-Dahlen at temperature $220 \ldots .240^{\circ} \mathrm{C}$.

For getting rusks, bread pieces were dried in the chamber stove Sveba-Dahlen at temperature $180^{\circ} \mathrm{C}$.

For preparing ring-shaped products, gold flax seeds were used. Gold flax seeds were dosed in the experimental samples as $5,10,15,20 \%$ of the flour mass. The control was a sample with the recipe: wheat flour of the first sort $-100 \mathrm{~g}$, yeast $-3 \%$, salt $-1.0 \%$.

Dough was mixed in two-speed dough-mixing machine Escher (Italy) during $20 \mathrm{~min}$ at the first speed. Mixed dough was left for $20 \mathrm{~min}$ for laying, after that it was rubbed with the following laying of dough. Dough semi-products were formed by hands and kept in the thermostat at temperature $(38 \pm 2){ }^{\circ} \mathrm{C}$ and relative humidity $(78 \pm 2) \%$ up to readiness. Before baking they were oiled in hot water with adding white sugar. The products were baked in the chamber stove Sveba-Dahlen at temperature $230^{\circ} \mathrm{C}$.

The quality control of the semi-products by humidity and acidity was realized by conventional methods [24].

The bread quality was estimated by the physical-chemical parameters (specific volume, form stability, acidity) [24].

The quality of rusks and ring-shaped products was estimated by the organoleptic parameters (outlook, surface state, porosity structure, color, taste, smell) and physical-chemical ones (mass share of humidity, acidity, soaking, swelling coefficient) [24]. 
The experimental research results were processed, using calculating methods of statistical reliability of measuring results. Approximation of empirical data was conducted by e-tables MSExcel (version of 2010).

\section{Results}

For establishing the influence of buckwheat flour on the technological process and quality of rusk products, at the beginning of the studies, there was investigated the influence of different dosages of green and dark buckwheat flour on the bread quality parameters, because simple rusks are obtained just of it after cutting and drying.

The analysis of the test laboratory baking results for making rusks of bread demonstrated (Fig. 1, Table 3) that adding dark buckwheat flour needs increasing the moisture mass share of dough. It is conditioned by the high water-absorbing capacity of flour.

Introduction of flour of both green and dark buckwheat increases both initial and final acidity of dough and crumble of the products. It is connected with the chemical composition of flour that contains acid-reacting substances in its composition.

It has been established, that the specific weight of bread increases with increasing the dosing amount of green buckwheat flour. But at introducing $25 \%$ it decreases abruptly.

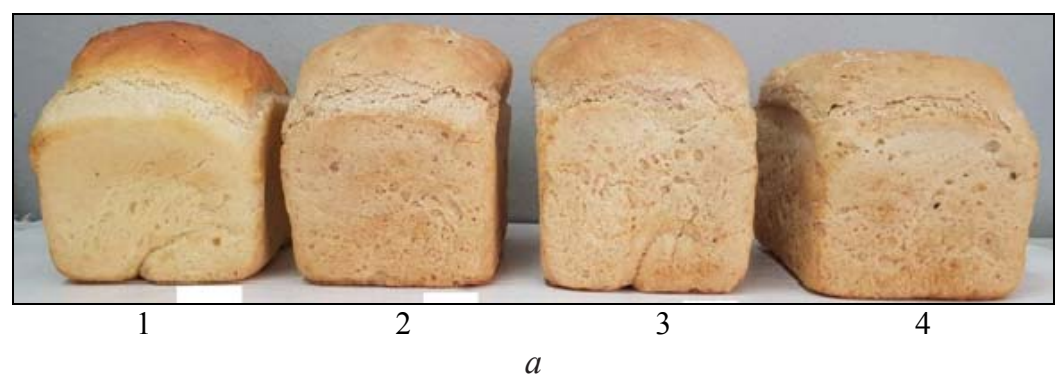

$a$

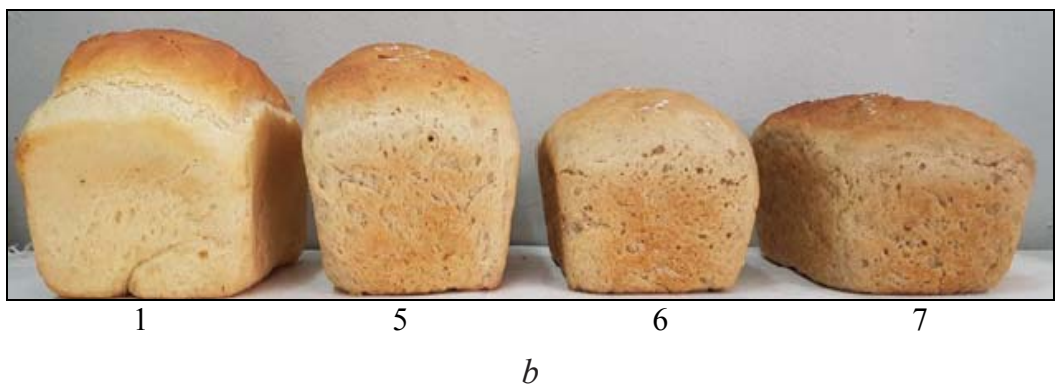

Fig. 1. Ready studied samples with replacement by flour of green (a) and dark (b) buckwheat: 1 - control; 2 - with replacement by $15 \%$ of green buckwheat flour; 3 - with replacement by

$20 \%$ of green buckwheat flour; 4 - with replacement by $25 \%$ of green buckwheat flour; 5 - with replacement by $15 \%$ of dark buckwheat flour; 6 - with replacement by $20 \%$ of dark buckwheat flour; 7 - with replacement by $25 \%$ of dark buckwheat flour

Introduction of dark buckwheat flour more than $15 \%$ instead of the mass of flour one essentially worsens the volume of the products and porosity index.

Taking into account the research results, we can make conclusion, that the best indices are inherent to the samples with introducing green buckwheat flour in amount $20 \%$, and the maximally permitted dosage of dark buckwheat flour is $15 \%$ instead of the flour mass.

The further studies of the quality of rusks, obtained of baked bread, were conducted with the aforesaid dosage of buckwheat flour.

It has been established (Table 4), that simple rusks with dark buckwheat flour need much more time for drying. 
Table 3

Parameters of the technological process and quality of bread of wheat flour of the highest sort with adding dark and green buckwheat flour

\begin{tabular}{|c|c|c|c|c|c|c|c|}
\hline \multirow{3}{*}{ Parameters } & \multirow{3}{*}{$\begin{array}{l}\text { Control (without } \\
\text { replacement) }\end{array}$} & \multicolumn{6}{|c|}{ Samples with replacement of \% of wheat flour by } \\
\hline & & \multicolumn{3}{|c|}{ green buckwheat flour } & \multicolumn{3}{|c|}{ dark buckwheat flour } \\
\hline & & 15 & 20 & 25 & 15 & 20 & 25 \\
\hline \multicolumn{8}{|c|}{ Dough } \\
\hline Mass share of humidity, $\%$ & 42.4 & 42.2 & 42.0 & 41.7 & 42.5 & 43.0 & 43.6 \\
\hline \multicolumn{8}{|l|}{ Titrated acidity, degrees: } \\
\hline - initial & 1.6 & 2.0 & 2.2 & 2.2 & 2.4 & 2.6 & 2.6 \\
\hline - final & 2.0 & 2.6 & 2.8 & 3.0 & 2.6 & 2.8 & 2.8 \\
\hline \multicolumn{8}{|c|}{ Ready products } \\
\hline Specific volume, $\mathrm{cm}^{3} / \mathrm{g}$ & 3.18 & 3.30 & 3.58 & 3.00 & 3.02 & 2.22 & 2.19 \\
\hline Mass share of humidity, $\%$ & 41.8 & 41.7 & 41.5 & 41.3 & 42.0 & 42.6 & 43.1 \\
\hline Porosity, \% & 73 & 74 & 75 & 72 & 72 & 70 & 70 \\
\hline Acidity, degrees & 1.2 & 1.6 & 1.6 & 1.8 & 1.4 & 1.4 & 1.6 \\
\hline
\end{tabular}

Table 4

Technological parameters of preparing simple rusks

\begin{tabular}{lccc}
\hline \multicolumn{1}{c}{ Parameter } & Control & $\mathbf{2 0} \%$ of green buckwheat flour & $\mathbf{1 5} \%$ of dark buckwheat flour \\
\hline Duration of keeping bread, hours & 8 & 8 & 8 \\
Thickness of pieces, $\mathrm{mm}$ & 12 & 12 & 12 \\
Drying temperature, ${ }^{\circ} \mathrm{C}$ & 180 & 180 & 180 \\
Drying duration, min & 30 & 30 & 45
\end{tabular}

The analysis of ready rusks demonstrated (Table 5, Fig. 2), that the sample with green buckwheat flour has a creamy color with a light grey tint, inherent to this type of flour, one with dark buckwheat flour - brown. The control porosity is fine, thin-walled, even; with green buckwheat flour - middle, thin-walled, even; with dark buckwheat flour - fine, thinwalled, even.

Table 5

Organoleptic quality parameters of simple rusks

\begin{tabular}{|c|c|c|c|}
\hline \multirow{2}{*}{ Parameter } & \multirow{2}{*}{ Control } & \multicolumn{2}{|c|}{ Samples with replacement of wheat flour by } \\
\hline & & $20 \%$ of green buckwheat flour & $15 \%$ of dark buckwheat flour \\
\hline \multicolumn{4}{|l|}{ Outlook: } \\
\hline form & \multicolumn{3}{|c|}{ Pieces, correspondent to the form of bread, which a rusk is dried of } \\
\hline surface & \multicolumn{3}{|c|}{ Without through cracks, with developed porosity, without unmixed spots, mould and pollution signs } \\
\hline color & \multicolumn{2}{|c|}{ Light-brown } & Dark-brown \\
\hline \multirow[b]{2}{*}{ Taste } & \multirow{2}{*}{$\begin{array}{l}\text { Inherent to this type of rusks, } \\
\text { without side smacks }\end{array}$} & \multicolumn{2}{|c|}{ Inherent to this type of rusks } \\
\hline & & With a buckwheat smack & $\begin{array}{c}\text { With a brightly expressed buckwheat } \\
\text { smack }\end{array}$ \\
\hline Smell & \multicolumn{3}{|c|}{ Inherent to this type of rusks, without side smells } \\
\hline
\end{tabular}




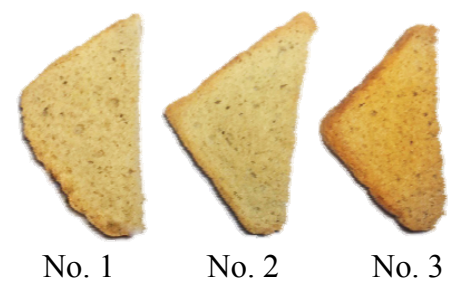

Fig. 2. Rusk products, produced of bred with adding buckwheat flour:

1 - control, 2 - with replacement by $20 \%$ of green buckwheat flour; 3 - with replacement by $15 \%$ of dark buckwheat flour

According to the data of Table 6, the humidity of the control sample and the one of the sample with green wheat buckwheat is within the standard. Rusks with adding dark buckwheat flour have higher humidity (14.0\%).

The duration of soaking rusks with adding dark buckwheat flour is 6 min $40 \mathrm{~s}$ that is in 4 times longer, than in the sample with green buckwheat flour and almost trice, than in the control sample (it is recommended no more $4 \mathrm{~min}$ ).

The most swelling coefficient is in the control sample, the least one - in the sample with green buckwheat flour. It is probably connected with sizes and thickness of crumble pores and their possibility to absorb water.

Table 6

Physical-chemical parameters of simple rusks with adding buckwheat flour

\begin{tabular}{cccc}
\hline Parameter & Control & $\mathbf{2 0} \%$ of green buckwheat flour & $\mathbf{1 5} \%$ of dark buckwheat flour \\
\hline Mass share of moisture in rusks, \% & 12.0 & 11.7 & 14.0 \\
Acidity, degrees & 2.2 & 3.4 & 4.0 \\
Soaking, min & $2: 30$ & $1: 40$ & $6: 40$ \\
Swelling coefficient & 7.2 & 4.8 & 5.1
\end{tabular}

So, by the parameters of moisture mass share and swelling, rusks with adding green buckwheat flour correspond to requirements of normative documents. Rusks with dark buckwheat flour need 1,5 times longer drying duration.

The results of enriching ring-shaped crackers with gold flax seeds testify that the products with $5 \%$ to the mass of flax seeds had a bit unpleasant smack of raw seeds. The dosage increase of seeds favors the formation of a pleasant original smack of fried seeds in products. Ready products with flax had inclusions of seeds on the surface. At the dosage increase of flax seeds, ready products get more intensive coloration of the surface and become more crumbling, comparing with the control. At dosage $20 \%$ of flax seeds to the flour mass, their chewing capacity a bit worsens together with forming pleasant taste properties.

According to the organoleptic estimation results of the ready products, the complex quality index was calculated. The complex quality index it is a total sum of points, obtained by an experimental sample at its analysis. For its calculation, each of organoleptic parameters of a product (outlook, crust color, crumble state, taste, smell) was estimated by the five point scale, taking into account the ponderability coefficient, established for each parameter by the method of expert estimation. That is a number of points, given to a parameter was multiplied on the ponderability coefficient. Then, the sum of obtained values was found. The maximal possible quality mark is 100 points. The more number of points is obtained by an experimental sample at the calculation, the better its organoleptic parameters are [25]. The expert commission included three doctors of technical sciences, five candidates of technical sciences, two PhD applicants and twelve higher education applicants of the speciality "Food technologies". 
The results of calculating the complex quality index of the control and experimental samples demonstrated (Fig. 3), that the sample with dosage $15 \%$ of flax seeds of the flour mass got most points. It allows to state that the dosage of flax seeds together with enriching a product with physiological-functional ingredients will favor the formation of the organoleptic parameters that satisfy a mass consumer.

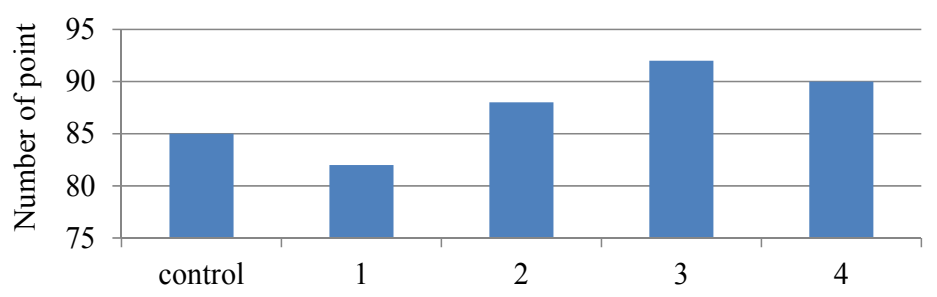

Fig. 3. Complex quality index of products with adding gold flax seeds: $1-5 \%$ of the flour mass; $2-10 \%$ of the flour mass; $3-15 \%$ of the flour mass; $4-20 \%$ of the flour mass.

The analysis of products by the physical-chemical parameters testified (Table 7) that introduction of flax seeds doesn't influence the acidity of ready products. The humidity of products at increasing the seeds dosage a bit decreases, probably, as a result of higher water-absorbing capacity of seeds.

Table 7

Physical-chemical parameters of ring-shaped crackers with adding flax seeds

\begin{tabular}{cccccc}
\hline \multirow{2}{*}{ Parameter } & Control & \multicolumn{3}{c}{ Samples with adding flax seeds, \% of the flour mass } \\
\cline { 3 - 6 } & & $\mathbf{5}$ & $\mathbf{1 0}$ & $\mathbf{1 5}$ & $\mathbf{2 0}$ \\
\hline Mass share of moisture of rusks, $\%$ & 12.5 & 12.3 & 12.0 & 11.4 & 11.0 \\
Acidity, degrees & 1.6 & 1.6 & 1.5 & 1.5 & 1.5 \\
Swelling coefficient & 4.3 & 4.0 & 3.8 & 3.5 & 3.0
\end{tabular}

It is noted, that the swelling coefficient of ring-shaped crackers with flax decreases corresponding to the dosage growth. It is probably connected with the fact that in ready products of the equal mass at the flax dosage growth, the flour content decreases at increasing the flax mass share.

\section{Conclusion}

The research results testify that the good quality parameters of bread for producing rusks were attained at green buckwheat flour dosage $20 \%$ and dark buckwheat $15 \%$ instead of the flour mass.

It has been established, that rusks with adding green buckwheat flour have the quality parameters, correspondent to requirements of normative documents.

It has been proven, that it is not expedient to use dark buckwheat flour in the rusk technology, because ready products have the increased water share and soaking index. It is connected with the influence of the operation of hydrothermal processing of grains that dark buckwheat flour is produced of, its high water-absorbing and water-retaining capacities.

Taking into account, that the rusk products with adding dark buckwheat flour had pleasant organoleptic parameters, it is necessary to continue the study as to establishing optimal parameters of their drying (temperature and duration) for attaining their physical-chemical parameters, correspondent to requirements of normative documents.

In the drying technology, enriched by flax seeds, it is recommended flax seeds dosage $15 \%$ of the flour mass. The products of such dosage obtained the maximal amount of points by the complex quality index and correspond to requirements of normative documents. In further it is expedient to conduct studies as to selecting the rational method and parameters of preparing dough 
for this product that allows to improve the products quality and to decrease technological losses for the production.

The results of these studies allow to produce long-stored bakery products with the increased food value and healthy properties. Its practical importance is in widening the assortment of longstored bakery products with healthy properties.

For confirming the status of these products of just healthy destination, it is necessary to calculate the chemical composition of the experimental samples and to compare it with the control one as to providing with important physiological-functional ingredients (food fibers, unsaturated fatty acids, mineral substances and vitamins).

In further it is also necessary to study changes of the organoleptic and physical-chemical parameters of the enriched products during the normative term of their storage.

\section{References}

[1] Kaur, S., Das, M. (2011). Functional foods: An overview. Food Science and Biotechnology, 20 (4), 861-875. doi: http:// doi.org/10.1007/s10068-011-0121-7

[2] Kaprelyants, L., Yegorova, A., Trufkati, L., Pozhitkova, L. (2019). Functional foods: prospects in Ukraine. Food Science and Technology, 13 (2), 15-23. doi: http://doi.org/10.15673/fst.v13i2.1382

[3] Dubinina, A. A., Popova, T. M., Lenert, S. O. (2014). Analyzing chemical composition of buckwheat groat of different buckwheat varieties. Eastern-European Journal of Enterprise Technologies, 4 (10 (70)), 58-62. doi: http://doi.org/10.15587/17294061.2014.26233

[4] Sots, S. M., Kustov, I. O. (2012). Tekhnolohichni vlastyvosti vitchyznianoho zerna holozernoho vivsa. Khranenye y pererabotka zerna, 4, 47-48.

[5] Shapovalenko, O. I., Skorikova, H. I., Korzh, T. V., Stepchuk, Yu. P. (2003). Pozhyvna tsinnist produktiv, vyhotovlenykhiz zerna krupianykh kultur. Khranenye y pererabotka zerna, 12, 44-45.

[6] Chauhan, D., Kumar, K., Kumar, S., Kumar, H. (2018). Effect of Incorporation of Oat Flour on Nutritional and Organoleptic Characteristics of Bread and Noodles. Current Research in Nutrition and Food Science Journal, 6 (1), 148-156. doi: http:// doi.org/10.12944/crnfsj.6.1.17

[7] Bilyk, O., Bondarenko, Y., Hryshchenko, A., Drobot, V., Kovbasa, V., Shutyuk, V. (2018). Studying the effect of sesame flour on the technological properties of dough and bread quality. Eastern-European Journal of Enterprise Technologies, 3 (11 (93)), 6-16. doi: http://doi.org/10.15587/1729-4061.2018.133233

[8] Yatsyshen, O. L., Taranenko, L. K. (2015). Perspektyvy vyroshchuvannia hrechky v Ukraini. Zbirnyk naukovykh prats NNTs «Instytut zemlerobstva NAAN», 3, 93-98.

[9] Drobot, V. I., Mikhonik, L. A., Grishhenko, A. N. (2009). Produkty funktsionalnogo naznacheniia. Mir produktov, 9, 6-8.

[10] Dubynyna, A., Popova, T., Lenert, S. (2014). Vitaminnyi i mineralnyi sklad krupiv iz hrechky. Tovary i rynky, 2, $106-115$.

[11] Juan, G., Yan, H., Zhengbiao, G. (2009). Studyon Physico-chemical Properties of Buckwheat Starch. Food and Fermentation Industries, 30 (11), 104-108.

[12] Przybylski, R., Gruczyska, E. (2009). A Review of Nutritional and Nutraceutical Components of Buck wheat. The European Journal of Plant Science and Biotechnology, 3 (1), 10-22.

[13] Drobot, V., Semenova, A., Smirnova, J., Mykhonik, L. (2014). Effect of Buckwheat Processing Products on Dough and Bread Quality Made from Whole-Wheat Flour. International Journal of Food Studies, 3 (1), 1-12. doi: http://doi.org/10.7455/ ijfs/3.1.2014.a1

[14] Grechka zelenaia. Available at: grechka-zelenaya.ru/o-grechke-zelenoj/sostav-grechki-zelenoj/himicheskij-sostav-grechki-zelenoj.html

[15] Ganorkar, P. M., Jain, R. K. (2013). Flaxseed - a nutritional punch. International Food Research Journal, 20 (2), $519-525$.

[16] Parikh, M., Raj, P., Austria, J. A., Yu, L., Garg, B., Netticadan, T., Pierce, G. N. (2019). Dietary flaxseed protects against ventricular arrhythmias and left ventricular dilation after a myocardial infarction. The Journal of Nutritional Biochemistry, 71, 63-71. doi: http://doi.org/10.1016/j.jnutbio.2019.06.004

[17] Rodriguez-Leyva, D., Weighell, W., Edel, A. L., LaVallee, R., Dibrov, E., Pinneker, R. et. al. (2013). Potent Antihypertensive Action of Dietary Flaxseed in Hypertensive Patients. Hypertension, 62 (6), 1081-1089. doi: http://doi.org/10.1161/hypertensionaha.113.02094

[18] Rashid, F., Ahmed, Z., Hussain, S., Huang, J.-Y., Ahmad, A. (2019). Linum usitatissimum L. seeds: Flax gum extraction, physicochemical and functional characterization. Carbohydrate Polymers, 215, 29-38. doi: http://doi.org/10.1016/j.carbpol. 2019.03.054 
[19] Soukoulis, C., Gaiani, C., Hoffmann, L. (2018). Plant seed mucilage as emerging biopolymer in food industry applications. Current Opinion in Food Science, 22, 28-42. doi: http://doi.org/10.1016/j.cofs.2018.01.004

[20] Touré, A., Xueming, X. (2010). Flaxseed Lignans: Source, Biosynthesis, Metabolism, Antioxidant Activity, Bio-Active Components, and Health Benefits. Comprehensive Reviews in Food Science and Food Safety, 9 (3), 261-269. doi: http:// doi.org/10.1111/j.1541-4337.2009.00105.x

[21] Marpalle, P., Sonawane, S. K., Arya, S. S. (2014). Effect of flaxseed flour addition on physicochemical and sensory properties of functional bread. LWT - Food Science and Technology, 58 (2), 614-619. doi: http://doi.org/10.1016/j.lwt.2014.04.003

[22] Marpalle, P., Sonawane, S. K., LeBlanc, J. G., Arya, S. S. (2015). Nutritional characterization and oxidative stability of $\alpha$-linolenic acid in bread containing roasted ground flaxseed. LWT - Food Science and Technology, 61 (2), 510-515. doi: http://doi. org/10.1016/j.lwt.2014.11.018

[23] Pourabedin, M., Aarabi, A., Rahbaran, S. (2017). Effect of flaxseed flour on rheological properties, staling and total phenol of Iranian toast. Journal of Cereal Science, 76, 173-178. doi: http://doi.org/10.1016/j.jcs.2017.05.009

[24] Drobot, V. I. (Ed.) (2015). Tekhnokhimichnyi kontrol syrovyny ta khlibobulochnykh i makaronnykh vyrobiv. Kyiv: NUKhT, 948.

[25] Lebedenko, T. Ie., Pshenyshniuk, H. F., Sokolova, N. Iu. (2014). Tekhnolohiia khlibopekarskoho vyrobnytstva. Praktykum. Odessa: «Osvita Ukrainy», 392.

\title{
STUDY OF QUALITY AND SAFETY PARAMETERS OF LIVER PASTES WITH AUBERGINE POWDER
}

\author{
Oksana Dzyundzya \\ Department of hotel and restaurant and tourist business \\ Kherson State University \\ 27 Universitetska str., Kherson, Ukraine, 73000 \\ Dzokvaok@gmail.com \\ Valentyna Burak \\ Department of Food Engineering \\ Kherson State Agricultural University \\ 23 Sretenskaya str., Kherson, Ukraine, 73006 \\ Irina Ryapolova \\ Department of Food Engineering \\ Kherson State Agricultural University \\ 23 Sretenskaya str., Kherson, Ukraine, 73006 \\ Nadiia Voievoda \\ Department of Food Engineering \\ Kherson State Agricultural University \\ 23 Sretenskaya str., Kherson, Ukraine, 73006

\section{Mariya Shinkaruk} \\ Department of Food Engineering \\ Kherson State Agricultural University \\ 23 Sretenskaya str., Kherson, Ukraine, 73006
}

